\title{
The Usefulness of M-B CDI-K Short Form as Screening Test in Children With Language Developmental Delay
}

\author{
Seong Woo Kim, $\mathrm{MD}^{1}$, Ha Ra Jeon, $\mathrm{MD}^{1}$, Eun Ji Park, MD${ }^{1}$, Hyo In Kim, MD', \\ Da Wa Jung, $\mathrm{MD}^{1}$, Mee Ryung Woo, $\mathrm{MA}^{2}$ \\ ${ }^{1}$ Department of Physical Medicine and Rehabilitation, \\ ${ }^{2}$ Speech Therapy Section, National Health Insurance Service Ilsan Hospital, Goyang, Korea
}

Objective: To investigate the usefulness of MacArthur-Bates Communicative Development Inventories-Korean (M-B CDI-K) short form as a screening test in children with language developmental delay.

Methods: From April 2010 to May 2012, a total of 87 patients visited the department of physical medicine and rehabilitation of National Health Insurance Service Ilsan Hospital with the complaint of language developmental delay and were enrolled in this study. All patients took M-B CDI-K short form and Sequenced Language Scale for Infants (SELSI) or Preschool Receptive-Expressive Language Scale (PRES) according to their age.

Results: The study group consisted of 58 male patients and 29 female patients and the mean age was 25.9 months. The diagnosis are global developmental delay in 26 patients, selective language impairment in 31 patients, articulation disorder in 7 patients, cerebral palsy in 8 patients, autism spectrum disorder in 4 patients, motor developmental delay in 4 patients, and others in 7 patients. Seventy-one patients are diagnosed with language developmental delay in SELSI or PRES and of them showed 69 patients a high risk in the M-B CDI-K short form. Sixteen patients are normal in SELSI or PRES and of them showed 14 patients non-high risk in the M-B CDI-K short form. The M-B CDI-K short form has $97.2 \%$ sensitivity, $87.5 \%$ specificity, a positive predictive value of 0.97 , and a negative predictive value of 0.88 .

Conclusion: The M-B CDI-K short form has a high sensitivity and specificity so it is considered as an useful screening tool in children with language developmental delay. Additional researches targeting normal children will be continued to supply the specificity of the M-B CDI-K short form.

Keywords Language development disorders, Sensitivity and specificity

Received November 7, 2013; Accepted March 19, 2014

Corresponding author: Ha Ra Jeon

Department of Physical Medicine and Rehabilitation, National Health Insurance Service Ilsan Hospital, 100 Ilsan-ro, Ilsandong-gu, Goyang 410-719, Korea

Tel: +82-31-900-0349, Fax: +82-31-900-0028, E-mail: snoopyhara@ hanmail.net

(c) This is an open-access article distributed under the terms of the Creative Commons Attribution Non-Commercial License (http://creativecommons. org/licenses/by-nc/3.0) which permits unrestricted noncommercial use, distribution, and reproduction in any medium, provided the original work is properly cited.

Copyright $\odot 2014$ by Korean Academy of Rehabilitation Medicine

\section{INTRODUCTION}

The physical growth of children draws a steep curve during the infancy. Likewise, their language abilities remarkably develop during this period. Ordinarily, children utter their first word when they are 12 months old and when they are 24 months old, they are able to pronounce more than 100 words [1]. However, some children may be behind others in language development. 
Children, who are at least one year behind others, are diagnosed as language developmental delay. It has been reported that language developmental delay occurs in $5 \%$ to $8 \%$ of the child population [2-4]. Language developmental delay is diagnosed by standardized assessment tools, such as the Sequenced Language Scale for Infants (SELSI) or the Preschool Receptive-Expressive Language Scale (PRES). Such assessments are conducted only by professionally-trained speech therapists and they are expensive and time consuming. Actually, it takes more than 30 or 40 minutes $[5,6]$. Such problems led to a need for a simple screening test that can be conducted prior to SELSI or PRES. The MacArther-Bates Communicative Development Inventories (M-B CDI) was developed and has been proved to be reliable and valid. Currently, it is used throughout the world, being translated into English, Danish, and Swedish [7-9]. Recently, a Korean version named M-B CDI-K was provided and its usefulness has been proved in a study [10]. However, the M-B $\mathrm{CDI}-\mathrm{K}$ is still expensive and time consuming because it was composed of many subsections. Besides, some questions are too professional for any respondents. Therefore, a M-B CDI-K short form version was developed in 2008 $[1,11]$. This test is divided into two types: one is for children aged between 9 and 17 months and the other one is for children aged between 18 and 35 months. The first type is composed of understanding score, expressing score, and playing with things score, and the second type is composed of understanding score, expressing score, and grammar score. It has the merit of being simple and easy enough to fill up brief questionnaires in a short time [1]. For these reasons, this study was carried out to investigate the effectiveness of M-B CDI-K short form as a screening test compared with SELSI or PRES.

\section{MATERIALS AND METHODS}

This study was conducted on 87 children whose chief complaints were speech and language delays and who visited the Department of Rehabilitation Medicine or the Developmental Delay Clinic of Ilsan Hospital between April 2010 and May 2012. The study protocol was approved by the ethics committee of the National Health Insurance Service Ilsan Hospital, Ilsan, Korea.

All children underwent physical and neurologic examinations by medical staff. Their parents or guardians filled up the M-B CDI-K short form, a screening test, after being given a speech therapist's explanation. In addition, the children took diagnostic language assessments according to their developmental age. Their cognitive functions were tested with Korean Bayley Scales of Infant Development-II (K-BSID-II) or Korean Wechsler Preschool and Primary Scale of Intelligence (K-WPPSI). Their language abilities were assessed with SELSI or PRES: the former was for children under the age of 3 years and the latter for preschoolers above the age of 3 years. But, SELSI was conducted in some children whose language levels were inadequate for PRES. Language developmental delay was defined as language age below 2 years as standard deviation of SELSI or language age was at least 1 year behind normal on the PRES $[5,6]$. In the M-B CDI-K short form, parents or guardians checked on words that children could understand or express, on their gestures or behaviors, and on the levels of their abilities to verbalize expression of sentence and grammatical sentence (Appendix 1). Based on the results, the children were classified into a high risk group and the non-high risk group. And then we compared the M-B CDI-K short form with SELSI or PRES [1].

\section{RESULTS}

This study included 87 children, 58 boys and 29 girls. Their average age was 25.9 months. Eighty-five out of 87 were tested with SELSI and the other 2 were tested with PRES (Table 1). We included 9 children aged between 37 to 38 months old because their language development stage was considered below 36 months. And 7 out of 9 children completed SELSI because they could not perform PRES. Twenty-six children were diagnosed with

Table 1. General characteristics of subjects

\begin{tabular}{|cc}
\hline Characteristic & No. (\%) \\
\hline Sex & \\
Male & $58(66.7)$ \\
\hline Female & $29(33.3)$ \\
Age (mo) & \\
\hline $0-2$ & $5(5.7)$ \\
\hline $13-24$ & $34(39.1)$ \\
\hline $25-36$ & $39(44.8)$ \\
\hline $37-38$ & $9(10.3)$ \\
\hline
\end{tabular}


global developmental delay, 31 with selective language impairment, 7 with functional articulation disorder, 8 with cerebral palsy, 4 with autism spectrum disorder, 4 with motor developmental delay, and the other 7 with reactive attachment disorder or quadriplegia caused by cerebral hemorrhage and so forth (Table 2).

The results of language assessments are as following: Twenty-six children were diagnosed with global developmental delay, 25 showed language developmental delay on SELSI or PRES and were tested positive for high risk on the M-B CDI-K short form. Another child showed a language developmental delay on SELSI or PRES but was

Table 2. Diagnosis of subjects

\begin{tabular}{|lc}
\hline \multicolumn{1}{c}{ Diagnosis } & No. (\%) \\
\hline Global developmental delay & $26(29.9)$ \\
\hline Specific language impairment & $31(35.6)$ \\
\hline Articulation disorder & $7(8.0)$ \\
\hline Cerebral palsy & $8(9.2)$ \\
\hline Autism spectrum disorder & $4(4.6)$ \\
\hline Motor developmental delay & $4(4.6)$ \\
\hline Other disorders & $7(8.0)$ \\
\hline
\end{tabular}

Table 3. Assessment results according to diagnosis

\begin{tabular}{|llcc}
\hline \multirow{2}{*}{ Diagnosis } & M-B CDI-K SF & \multicolumn{2}{c}{ SELSI or PRES } \\
\cline { 2 - 4 } & Normal & Delay \\
\hline GDD & High risk & 0 & 25 \\
& Non-high risk & 0 & 1 \\
\hline \multirow{2}{*}{ SLI } & High risk & 1 & 29 \\
& Non-high risk & 1 & 0 \\
\hline AD & High risk & 0 & 0 \\
\hline \multirow{2}{*}{ CP } & Non-high risk & 7 & 0 \\
\hline \multirow{2}{*}{ ASD } & High risk & 2 & 5 \\
\hline \multirow{2}{*}{ MDD } & Non-high risk & 0 & 1 \\
\hline & High risk & 0 & 4 \\
\hline & Non-high risk & 0 & 0 \\
\hline
\end{tabular}

M-B CDI-K, MacArthur-Bates Communicative Development Inventories-Korean; SF, short form; SELSI, Sequenced Language Scale For Infants; PRES, Preschool Receptive-Expressive Language Scale; GDD, global developmental delay; SLI, specific language impairment; $\mathrm{AD}$, articulation disorder; $\mathrm{CP}$, cerebral palsy; ASD, autism spectrum disorder; MDD, motor developmental delay. negative tested for high risk on the M-B CDI-K short form. Of 31 children diagnosed with selective language impairment, 29 showed language developmental delay on SELSI or PRES and were positive tested on the M-B CDI-K short form. One child did not show language developmental delay on SELSI or PRES but was positive tested on the M-B CDI-K short form, another child did not show language developmental delay on SELSI or PRES and was negative tested on the short form M-B CDI-K. The seven children diagnosed with functional articulation disorder did not show language developmental delay on SELSI or PRES and were negative tested on the short form M-B CDI-K. Of eight children diagnosed with cerebral palsy showed five a language developmental delay on SELSI or PRES and were positive tested on the M-B CDI-K short form, two did not show language developmental delay on SELSI or PRES but were positive tested on the M-B CDI-K short form. Another child showed language developmental delay on SELSI or PRES but was negative tested on the M-B CDI-K short form. Four children diagnosed with autism spectrum disorder showed language developmental delay on SELSI or PRES and were positive tested on the M-B CDI-K short form. Four children diagnosed with motor developmental delay showed language developmental delay on SELSI or PRES and were negative tested on the M-B CDI-K short form (Table 3).

In our final analysis, 71 children showed language developmental delay on SELSI or PRES and 69 of them were positive tested for a high risk on the M-B CDI-K short form. Of 16 children without language developmental delay on SELSI or PRES were 14 negative tested for high risk on the M-B CDI-K short form. As for the M-B CDI-K short form, the sensitivity and specificity reached $97.2 \%$ and $87.5 \%$, respectively and the positive predictive value and negative predictive value were worked out at 0.97 and 0.88 , respectively (Table 4 ).

Table 4. Accuracy of M-B CDI-K short form

\begin{tabular}{|lc}
\hline Sensitivity (\%) & 97.2 \\
\hline Specificity (\%) & 87.5 \\
\hline Predictive value & \\
\hline Positive & 0.97 \\
\hline Negative & 0.88 \\
\hline
\end{tabular}

M-B CDI-K, MacArthur-Bates Communicative Development Inventories-Korean. 


\section{DISCUSSION}

Language developmental delay was easily observed in children with delayed development. In previous studies was language developmental delay reported as chief complaint in $41 \%$ of children who visited the children development clinic [12]. Since language developmental delay may improve with advancing years, there were a lot of controversies over treatment timing, therapeutic effects and necessity. However, it may negatively influence children's abilities to communicate, learn, and socialize if it is not diagnosed and treated early [2,13]. Thus, an early screening test is crucial for early diagnosis and treatment.

The M-B CDI-K short form has various advantages to evaluate the language developmental delay in infants and children [1]. It can be conducted even by nonprofessionals and sets fewer questions than other existing assessment tools and thus, it saves time and is economical. Actually, it can be finished within 5 minutes. Vocabularies used in the M-B CDI-K short form covered vocabularies of the original version and had a high relevance to the original. So, the M-B CDI-K short form provided high reliability [1]. However, we must not confirm the diagnosis of language developmental delay when children were positive tested for a high risk on the M-B CDI-K short form because it was just a screening test. Therefore, more detailed assessments should be given to children judged to be in the high risk group. Also it should be considered that the test may be subjective because the questionnaires were filled up by parents or guardians.

The Denver Developmental Screening Test (DDST) or the Ages and Stages Questionnaire (ASQ) has been used to assess the developmental status, but they have been found to be inferior to the M-B CDI-K short form regarding their sensitivity and specificity [14-17]. Further, there was a report that DDST is valueless as a screening test for speech and language development [18]. Therefore, DDST had a low value as a speech and language screening test.

In this study, there were about two times more boys than girls. It showed a similar ratio to previous studies where boys and girls with language developmental disorder as chief complaint were at a ratio of 2:1 to $3: 1[2,19]$.

The M-B CDI-K short form has been found to be costsaving, time-saving, reliable, and valid, and thus can be an effective screening test for speech and language development. Commonly, screening tests are regarded as effective when their sensitivities and specificities reach at least $70 \%$ to $80 \%$. The M-B CDI-K short form satisfied such conditions as its sensitivity and specificity reach $97.2 \%$ and $87.5 \%$, respectively [20,21].

This study was conducted with 87 children whose chief complaints were speech and language delay and who visited the Department of Rehabilitation Medicine or the Developmental Delay Clinic at our hospital between April 2010 and May 2012. The study was carried out to investigate the effectiveness of the M-B CDI-K short form as a screening test, comparing it with SELSI or PRES. As a result, the M-B CDI-K short form showed a high sensitivity $(97.2 \%)$, specificity $(87.5 \%)$, positive predictive value (0.97), and negative predictive value (0.88). The results suggest that the M-B CDI-K short form may be effective to screen children suspected to have language developmental delay. Further study is needed about the M-B CDI-K short form including more children with normal and various diseases.

\section{CONFLICT OF INTEREST}

No potential conflict of interest relevant to this article was reported.

\section{REFERENCES}

1. Pae SY, Kwak KJ, Kim MB, Lee HS, Jung KH. Short form versions of MacArthur-Bates Communicative Development Inventories - Korean (M-B CDI-K). Korean J of Speech Sci 2008;15:119-29.

2. Jang JH, Park ES, Park JH, Baek JH, Won YH, Rha DW. Clinical usefulness of Capute developmental test as a screening test for detecting the language delay. J Korean Acad Rehabil Med 2010;34:544-9.

3. Randall D, Reynell J, Curwen M. A study of language development in a sample of 3 year old children. $\mathrm{Br} \mathrm{J}$ Disord Commun 1974;9:3-16.

4. Burden V, Stott CM, Forge J, Goodyer I. The Cambridge Language and Speech Project (CLASP). I. Detection of language difficulties at 36 to 39 months. Dev Med Child Neurol 1996;38:613-31.

5. Kim YT, Kim KH, Yoon HR, Kim WS. Sequenced language scale for infants (SELSI). 1st ed. Seoul: Special Education Publication Co.; 2003.

6. Kim YT, Sung TJ, Lee YK. Preschool receptive-expres- 
sive language scale (PRES). 1st ed. Seoul: Seoul Welfare Center for People with Disabilities; 2003.

7. Reese E, Read S. Predictive validity of the New Zealand MacArthur Communicative Development Inventory: words and sentences. J Child Lang 2000;27:25566.

8. Westerlund M, Berglund E, Eriksson M. Can severely language delayed 3-year-olds be identified at 18 months? Evaluation of a screening version of the MacArthur-Bates Communicative Development Inventories. J Speech Lang Hear Res 2006;49:237-47.

9. Vach W, Bleses D, Jorgensen R. Construction of a Danish CDI short form for language screening at the age of 36 months: methodological considerations and results. Clin Linguist Phon 2010;24:602-21.

10. Lee YK. The relationships among language, communicative abilities and motor, cognitive, and socio-emotional development in toddlers with language delays. Korean J of Commun Disord 2011;16:1-12.

11. Pae SY. Validity and reliability of the Korean adaptation of MCDI. Korean J of Commun Disord 2003;8:114.

12. Harel S, Greenstein Y, Kramer U, Yifat R, Samuel E, Nevo $Y$, et al. Clinical characteristics of children referred to a child development center for evaluation of speech, language, and communication disorders. Pediatr Neurol 1996;15:305-11.

13. Kim SW, Shin JB, You S, Yang EJ, Lee SK, Chung HJ, et al. Diagnosis and clinical features of children with lan- guage delay. J Korean Acad Rehabil Med 2005;29:58490.

14. Glascoe FP, Byrne KE, Ashford LG, Johnson KL, Chang B, Strickland B. Accuracy of the Denver-II in developmental screening. Pediatrics 1992;89(6 Pt 2):1221-5.

15. Ga HY, Kwon JY. A comparison of the Korean-ages and stages questionnaires and Denver developmental delay screening test. Ann Rehabil Med 2011;35:369-74.

16. Deakin-Bell N, Walker K, Badawi N. The accuracy of parental concern expressed in the Ages and Stages Questionnaire to predict developmental delay. J Paediatr Child Health 2013;49:E133-6.

17. Guiberson M, Rodriguez BL. Measurement properties and classification accuracy of two spanish parent surveys of language development for preschool-age children. Am J Speech Lang Pathol 2010;19:225-37.

18. Borowitz KC, Glascoe FP. Sensitivity of the Denver Developmental Screening Test in speech and language screening. Pediatrics 1986;78:1075-8.

19. Kim SW, Shin JB, Kim EH, Lee SK, Jung HJ, Song DH. Diagnosis and clinical features in children referred to developmental delay Clinic. J Korean Acad Rehabil Med 2004;28:132-9.

20. Rydz D, Shevell MI, Majnemer A, Oskoui M. Developmental screening. J Child Neurol 2005;20:4-21.

21. Frankenburg WK. Developmental surveillance and screening of infants and young children. Pediatrics 2002;109:144-5. 
Appendix 1. MacArthur-Bates Communicative Development Inventories-Korean (M-B CDI-K) short form

\begin{tabular}{|c|c|c|c|}
\hline 범주(category) & 단어(word) & 표현(expression) & 이해(understanding) \\
\hline \multirow[t]{4}{*}{ 소리(sound) } & 꼬끼오(cock-a-doodle-doo) & & \\
\hline & 똑똑(tap-tap) & & \\
\hline & 야옹(mew) & & \\
\hline & 음매(moo) & & \\
\hline \multirow{2}{*}{ 탈 것(vehicle) } & 버스(bus) & & \\
\hline & 택시(taxi) & & \\
\hline \multirow[t]{5}{*}{ 동물(animal) } & 곰(bear) & & \\
\hline & 돼지(pig) & & \\
\hline & 사자(lion) & & \\
\hline & 오리(duck) & & \\
\hline & 하마(hippo) & & \\
\hline \multirow{5}{*}{ 신체부위(part of body) } & 눈(eye) & & \\
\hline & 머리(head) & & \\
\hline & 배꼽(navel) & & \\
\hline & 이/이빨(tooth) & & \\
\hline & 팔(arm) & & \\
\hline \multirow[t]{2}{*}{ 옷(clothes) } & 단추(button) & & \\
\hline & 양말(socks) & & \\
\hline \multirow[t]{3}{*}{ 장난감(toy) } & 공(ball) & & \\
\hline & 종이(paper) & & \\
\hline & 총(gun) & & \\
\hline \multirow[t]{9}{*}{ 음식(food) } & 고구마(sweet potato) & & \\
\hline & 귤(tangerine) & & \\
\hline & 꿀(honey) & & \\
\hline & 맘마(rice) & & \\
\hline & 밤(chestnut) & & \\
\hline & 사과(apple) & & \\
\hline & 아이스크림(icecream) & & \\
\hline & 주스(juice) & & \\
\hline & 포도(grape) & & \\
\hline \multirow[t]{4}{*}{ 가정용품(housewear) } & 빗(brush) & & \\
\hline & 안경(glasses) & & \\
\hline & 전화(telephone) & & \\
\hline & 컵(cup) & & \\
\hline \multirow[t]{2}{*}{ 방안(interior of the room) } & 베개(pillow) & & \\
\hline & 텔레비전(television) & & \\
\hline 장소(place) & 병원(hospital) & & \\
\hline \multirow[t]{3}{*}{ 외부사물(external things) } & 꽃(flower) & & \\
\hline & 돌(stone) & & \\
\hline & 비(rain) & & \\
\hline
\end{tabular}




\begin{tabular}{|c|c|c|c|}
\hline 범주(category) & 단어(word) & 표현(expression) & 이해(understanding) \\
\hline \multirow[t]{5}{*}{ 사람(person) } & 고모(aunt) & & \\
\hline & 아가(baby) & & \\
\hline & 언니(sister) & & \\
\hline & 아동이름(baby's name) & & \\
\hline & 형(brother) & & \\
\hline \multirow{3}{*}{ 일상생활(daily life) } & 빠이빠이(bye-bye) & & \\
\hline & 아니(no) & & \\
\hline & 응가/똥(poo) & & \\
\hline \multirow[t]{2}{*}{ 대신 하는말(lansign) } & 나/내(I/my) & & \\
\hline & 이거/요거(this/that) & & \\
\hline 양(amount) & 더(more) & & \\
\hline \multirow[t]{11}{*}{ 동사(verb) } & 가(go) & & \\
\hline & (불)꺼(turn off) & & \\
\hline & 넣어(put) & & \\
\hline & 닦아(wash) & & \\
\hline & (주사)맞아(get) & & \\
\hline & 봐(see) & & \\
\hline & 신어(wear) & & \\
\hline & 안해(do not) & & \\
\hline & 올라가(climb) & & \\
\hline & 읽어(read) & & \\
\hline & (공)차(kick) & & \\
\hline \multirow[t]{5}{*}{ 형용사(adjective) } & 같아/똑같아(same) & & \\
\hline & 뜨거워(hot) & & \\
\hline & 무서워(scary) & & \\
\hline & 아파(sick) & & \\
\hline & 좋아(good) & & \\
\hline \multirow[t]{3}{*}{ 기능어(function word) } & -랑(엄마랑)(with) & & \\
\hline & -고(먹고)(and) & & \\
\hline & -요(가요)(honorific) & & \\
\hline
\end{tabular}




\begin{tabular}{|c|c|c|}
\hline \multicolumn{3}{|l|}{ 사물가지고 놀기(playing with things) } \\
\hline 1. 장난감 차나 트럭을 민다.(He/she can push toy car or truck.) & 함(can) & 안함(can’t) \\
\hline 2. 공을 던진다.(He/she can throw a ball.) & 함(can) & 안함(can’t) \\
\hline 3. 스푼이나 포크로 먹는다.(He/she can eat using spoon or fork.) & 함(can) & 안함(can’t) \\
\hline 4. 컵으로 음료수를 마신다.(He/she can drink beverage from a cup.) & 함(can) & 안함(can’t) \\
\hline 5. 자신의 머리를 빗는다.(He/she can comb his/her hair.) & 함(can) & 안함(can’t) \\
\hline 6. 이를 닦는다.(He/she can brush his/her teeth.) & 함(can) & 안함(can't) \\
\hline 7. 수건으로 얼굴이나 손을 닦는다.(He/she can wash his/her face or hands with a towel.) & 함(can) & 안함(can’t) \\
\hline 8. 모자를 쓴다.(He/she can wear his/her hat.) & 함(can) & 안함(can’t) \\
\hline 9. 양말 또는 신발을 신는다.(He/she can wear socks or shoes.) & 함(can) & 안함(can’t) \\
\hline 10. 목걸이, 팔찌, 시계를 찬다.(He/she can wear a necklace, bracelet or watch.) & 함(can) & 안함(can't) \\
\hline $\begin{array}{l}\text { 11. 잠자는 척하며, 머리에 손 베개를 하거나 눈을 감는다. } \\
\text { (He/she can close his/her eyes pretending to sleep.) }\end{array}$ & 함(can) & 안함(can't) \\
\hline $\begin{array}{l}\text { 12. 뭔가 뜨겁다는 것을 나타내려 호호 분다. } \\
\text { (He/she can blow his/her breath to sign something is hot.) }\end{array}$ & 함(can) & 안함(can’t) \\
\hline 13. 장난감비행기를 잡고 하늘을 나는 시늉을 한다.(He/she can pretend to fly with a toy plane.) & 함(can) & 안함(can’t) \\
\hline 14. 전화수화기를 귀에 갖다 댄다.(He/she can apply the receiver to his/her ear.) & 함(can) & 안함(can't) \\
\hline 15. 꽃냄새를 맡는다.(He/she can smell the flowers.) & 함(can) & 안함(can’t) \\
\hline $\begin{array}{l}\text { 16. 이 컵에서 저 컵으로 음료수를 따르는 시늉을 한다. } \\
\text { (He/she can pretend to pour drinking water into a cup.) }\end{array}$ & 함(can) & 안함(can't) \\
\hline $\begin{array}{l}\text { 17. 숟가락으로 컵에 든 액체를 젓는 시늉을 한다. } \\
\text { (He/she can pretend to whisk liquid with a spoon in the cup.) }\end{array}$ & 함(can) & 안함(can't) \\
\hline
\end{tabular}

